\title{
Filozoficzne aspekty „bez-względności” słowa w relacji dorosły - małe dziecko
}

\begin{abstract}
Abstrakt
W artykule podejmuję próbę ukazania obecności słowa - żywego słowa - jako środka języka/mowy w relacji jednego człowieka z Drugim - z kimś bliższym niż ktoś inny, kto swoją obecnością poświadcza obecność tego, który do niego mówi. 0 obecności słowa można mówić jako o obecności bezwzględnej - zgodnie z myśleniem o języku/mowie przez pryzmat ich konwencjonalnie rozumianych funkcji. Przyjmując za H.-G. Gadamerem, że nasze doświadczenie ma postać językową, piszę o zanurzeniu w języku, w którym, poprzez przyswojenie sobie jego znaczeń, możemy myśleć i komunikować swoje myśli innym oraz komunikować się z nimi - rozmawiać. Obecność słów jako podstawy, możliwości i jakości relacji jednego człowieka z Drugim ma także względny charakter. Za E. Lévinasem przedstawiam prelingwistyczny sposób bycia jednego człowieka z Drugim oraz omawiam milczenie jako pozornie nie-słowny kontakt z sobą samym i z Drugim. Ponieważ koncentruję się na relacji z Drugim, rozwijam także wątek tego, kto mówi do kogo, tym samym wskazując, że mówienie do kogoś mieści się w „projekcie egzystencjalnym" mówiącego. Rozważania skoncentrowane wokół powyższej problematyki stały się także pretekstem do podjęcia refleksji nad wybranymi aspektami słownej i niesłownej relacji między dorosłym a małym dzieckiem. Podjęte w artykule rozważania sytuuję przede wszystkim w perspektywie fenomenologicznej.
\end{abstract}

Słowa kluczowe: słowo, M(m)ówienie, milczenie, relacja, fenomenologia.

\section{Philosophical aspects of "non-relativity" of the word in the adult - young child relationship}

\begin{abstract}
This article is an attempt of showing the presence of the word - the living word - as a linguistic/speech means in human being's relation with the Other - with somebody closer than somebody else, who testifies with his/her presence to the presence of the person speaking to him/her. The presence of the word can be perceived as "non-relative"
\end{abstract}

* Uniwersytet Łódzki, Wydział Nauk o Wychowaniu, Katedra Teorii Wychowania. 


\begin{abstract}
presence - in line with thinking about language/speech through the prism of their conventionally understood functions. Accepting after H.-G. Gadamer that our experience is linguistic in nature, I write about immersion in language in which, by assimilating its meanings, we can think and communicate our thoughts to others and communicate with them - we are able to talk. The presence of words as the foundation, opportunity and quality of relations with the Other is also relative in its nature. I present, following the ideas of E. Lévinas, the pre-linguistic way of being with the Other and I discuss silence as seemingly non-verbal contact with oneself and the Other. Since I focus on the relation with the Other, I also develop the theme of who is talking to whom, pointing out, at the same time, that talking to somebody fits in the "existential project" of the speaker. The considerations concentrated on the above problems became also a pretext to reflect on the selected aspects of verbal and nonverbal relation between an adult and a young child. The reflections undertaken in the article are mostly placed within the phenomenological perspective.
\end{abstract}

Keywords: word, S(s)peaking, silence, relation, phenomenology.

\title{
Wprowadzenie
}

Jak tworzyć sztukę słowa w przestrzeni intersubiektywnej, gdy w codzienności mamy do czynienia z jego hipertrofią - przepełnieniem intersubiektywności słowami. Słowa powszechne, które są włóknami tkaniny codzienności, jej spoiwem i wzorem, stają się także słowami powierzchownymi, i choć są zwykłe i zwyczajne, to w coraz większym stopniu dzisiaj zużyte. Toniemy - jak powiedziałby Karl Jaspers - w bezmiernej masie pustych słów (Jaspers 1990: 240). Za Merleau-Ponty dopowiem - „(...) trzy czwarte z tego, co się słyszy, nie zwraca niczyjej uwagi", a to dlatego, że po pierwsze tzw. mowa pierwszego stopnia, polegająca na przekazywaniu informacji o zdarzeniach, stanach rzeczy, ideach et cetera jest mową jednoznaczną - wymaga się od niej, by nie budziła podejrzeń co do prawdziwości przekazu treści (Merleau-Ponty 1999: 38). Po drugie mowa drugiego stopnia, jak dialog, rozmowa, prośba, a nawet zwierzenia „uchodzi po prostu za zbiór form kanonicznych”, a zatem także wyuczanych i obiegowych w użyciu (tamże: 38). Ponadto w powszechnych słowach, tych powtarzających się codziennie, ale i od święta, niełatwo rozpoznać ich wyjątkowość.

Jeśli mowa jako akt ekspresji widziany z perspektywy fenomenologicznej, u którego podłoża leży bezpośrednie i ucieleśnione zaangażowanie w świecie, usytuowane w jakimś kontekście (fizycznym, społecznym, kulturowym) i będące procesem czasowym, zwane zazwyczaj percepcją, a co za tym idzie i jego znajomość, miałaby być uwarunkowana zdobyciem i przyswojeniem znaczeń słów jako reprezentacji czegoś, to pod znakiem zapytania jest możliwość nie tylko rozumienia, ale odbioru mowy małego dziecka, czy w ogóle przyznania pewnej formie jego ekspresji egzystencjalnej kategorii mowy¹. Małe dziecko jednak mówi - i mówi do dorosłego.

\footnotetext{
1 Por. „Dla was, którzy też kochają Małego Księcia, tak samo jak dla mnie, nic nie jest podobne we wszechświecie do tego zdarzenia: gdy w jakimś miejscu na świecie, nie wiadomo gdzie, jakiś nieznany
} 
Jakie jest znaczenie obecności/nieobecności słowa w relacji dorosły - małe dziecko², jeśli przyjmie się za Hansem Georgiem Gadamerem założenie, że doświadczenie jednego i drugiego ma postać językową, a zatem jeden i drugi spotykając się ze sobą, już są zanurzeni w języku? Jeśli zaś postawimy tezę, że językowa postać doświadczenia podmiotu jest wtórna w stosunku do prelingwistycznego sposobu jego bycia, to zarazem wypada przyjąć, że mówienie do Drugiego mieści się w „projekcie egzystencjalnym” tego, kto mówi. To filozoficzny, moim zdaniem niezbywalny, kontekst wypowiedzi o niuansach obecności/nieobecności słowa w relacji dorosły - małe dziecko jako Drugi. A Drugi to ten oto, a nie jeden z wielu, choćby oznaczony nazwą dla nich wspólną. Małe dziecko jako Drugi jest takie jak dorosły ${ }^{3}$, choćby dzielił ich przeżyty czas, ale nie jest ono takie samo jak dorosły. Małe dziecko jako Drugi jest bliższe niż ktoś inny, choćby z racji swojego położenia wobec dorosłego. Zarazem małe dziecko jako Drugi poświadcza znaczenie obecności wobec niego dorosłego - dorosły nie musi szukać innych świadków, ono jest „pod ręką”, było lub będzie. I również dorosły, będąc z małym dzieckiem, poświadcza znaczenie jego obecności ${ }^{4}$.

\section{Mówienie (le dire) - pierwotna intersubiektywność}

To, co powiedziane w języku, wypowiada zawsze bycie. Jednak język, stając się zagadką, uwalnia się także od swoich uwarunkowań (...) i wypowiada znaczenie poprzedzające wydarzenie - to co przed-byciem. (Lévinas 2000: 197)

Emmanuel Lévinas zapytuje: „Jednak czy w człowieku zdolność mówienia - niezależnie od tego, jak ściśle jego funkcja jest związana z Powiedzianym - pozostaje w służbie bycia?" (Lévinas 2000: 67). Jeśli uznać, że w tym pytaniu skrywa się założenie o znaczeniu Mówienia ${ }^{5}$ przed Powiedzianym, a na to wskazuje lektura Inaczej niż być lub ponad istota, to jako odpowiedź można przytoczyć następujące jego słowa: „(...) znaczenie Mówienia - sięgające ponad istotę zebraną w Powiedzianym - będzie uzasadniało ekspozycję bycia (...)” (tamże: 68). Te słowa odsyłają

nam baranek zjadł lub nie zjadł jakąś różę. Spójrzcie na niebo. Zadajcie sobie pytanie, czy baranek zjadł, czy też nie zjadł Róży? I zobaczycie, jak wszystko się zmienia. A żadna dorosła osoba nie pojmie nigdy, że to ma tak wielkie znaczenie!" (de Saint-Exupéry 2000: 78).

2 Małe dziecko to dziecko w wieku przedprzedszkolnym, tzn. od 0 do 3 lat. Z psychologicznego punktu widzenia to właśnie w tym okresie kształtuje się podstawa dalszego rozwoju człowieka.

${ }^{3}$ W tym miejscu warto przywołać znane stwierdzenie Janusza Korczaka, mówiące o tym, że nie ma dzieci - są ludzie.

4 To pozytywna konotacja Drugiego i taką jej wykładnię przyjmuję w artykule (por. Walczak 2011: 89-99).

${ }^{5}$ Kiedy piszę o Mówieniu w ujęciu Lévinasa, słowo to zapisuję z wielkiej litery, kiedy zaś chodzi o mówienie/mowę jako ruch i konfigurację słów oraz gestów emocjonalnych zwanych mową ciała w ujęciu innych autorów - z małej. 
nas do „przedontologicznego ciężaru języka”. Emmanuel Lévinas w przytoczonym dziele używa określenia „przed-mowa”, podkreślając, że Mówienie jest tym, co pierwotne, pierwsze, źródłowe dla powiedzianego (w powiedzianym) (tamże: 15). Zanim słowo zostanie wy-powiedziane spotykamy się nie z myślą o tym, o czym ma być wypowiedź, ale z czymś pierwotniejszym - z prelingwistycznym sposobem bycia.

Lévinas ujmuje Mówienie jako odpowiedzialność (substytucję) ${ }^{6}$ - bierne otwarcie się na Drugiego i bezinteresowne zbliżanie się do niego, zarazem uzewnętrzniając się, odkrywając się, wystawiając się, wyrażając się dając siebie i ryzykując (tamże: 83-84). Bierność otwarcia się nie odwołuje do zaangażowania, które zazwyczaj sprowadza się do wolności wyboru (tamże: 89, 128). Zaangażowanie zakłada Mówienie - nieobojętność na Drugiego jako ekspresję siebie będącą wydarzeniem niemożliwym do przedstawienia w słowie wyrażonym w języku konwencjonalnym, choć w nim jakby „zamieszkiwało”. Jak dokonuje się przemiana Mówienia - „czystego wyrażania siebie poprzez dawanie znaku Drugiemu (języka poprzedzającego Powiedzenie) - w Mówienie wypowiadające pewne Powiedzenie"? (tamże: 106). Co znaczy Powiedziane?

\section{Powiedziane (dit) - proza intersubiektywności}

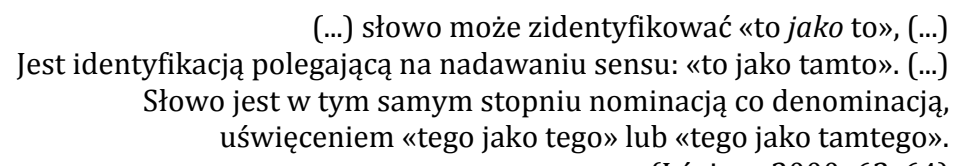

(Lévinas 2000: 62, 64)

Lévinas Powiedzianemu nie przyznaje pierwszeństwa, traktując je jako wtórne w stosunku do pierwotnej sfery intersubiektywnej - Mówienia. Zarazem Mówienie „wystawia się” na swe językowe znaczenia, a cofnięcie się do niego i jego odsłonięcie jest możliwe tylko za pośrednictwem Powiedzianego (tamże: 84). W Powiedzianym dokonuje się bowiem wy-powiedzenie siebie do Drugiego i wypowiedzenie się o Drugim. I jest ono wysławiane w medium języka, który w ujęciu Lévinasa - jako właśnie Powiedziane - sprowadzony zostaje do systemu znaków wytworzonych/wytwarzanych w danej kulturze, które są komunikowane i/lub służą do komunikowania się ze sobą (tamże: 71). Hans Georg Gadamer powie, że w języku komunikatywnie realizuje się rozum (2008: 93), co stanowi zasadę tworzenia sfery intersubiektywności - spotkania jednego człowieka z Drugim7. Można zatem

\footnotetext{
${ }^{6}$ Mogę nie podjąć odpowiedzialności za Drugiego, ale nie mogę jej zignorować jakimś aktem myślenia lub działania. Ekspozycję tej problematyki w postaci wykładni epifanii twarzy odnajdujemy we wcześniejszym dziele Lévinasa pt. Całość i nieskończoność. Esej o zewnętrzności (Lévinas 1998).

7 Również z samym sobą, o czym mówi dobitnie Paul Ricoeur w książce pt. $O$ sobie samym jako innym (Ricoeur 2005).
} 
powiedzieć, że sfera ta tworzy się z „wnętrza języka” (Gadamer 1993: 429-430), który zazwyczaj jest kojarzony ze słowem ${ }^{8}$.

Słowo pełni funkcję znaku - faktu dźwiękowego lub graficznego i zazwyczaj wiążącego się z nazywaniem czegoś i wyrażaniem myśli. Myśl i słowo są ze sobą splecione w rzeczywistości - i jak powie Merleau-Ponty - „sens jest uchwycony w słowie, zaś słowo jest zewnętrznym istnieniem sensu”. I zważywszy na tę wzajemną relację tym bardziej nie można przyjąć - zdaniem Merleau-Ponty - że „słowo jest zwykłym środkiem utrwalania myśli”, jej obwieszczeniem, tak jak „dym obwieszcza ogień” (Merleau-Ponty: 1999: 91). Merleau-Ponty określił jako „fantom czystego języka” powszechne uznanie wcześniejszych znaczeń języka jako podstawy do jego rozumienia, stanowiące potoczną teorię mowy (tamże: 38-44) ${ }^{9}$. Już w codziennym użyciu języka, sprowadzonym do korespondencji między danym znakiem i danym znaczeniem, rychło doświadczamy, że on sam nie jest bezwzględnie jasny, ponieważ nie można orzec, że „żadna myśl zbędnie nie błąka się w wyrazach ani żaden wyraz w samej myśli o niej” (tamże: 39). Jak pisze Merleau-Ponty „mowa nie jest nigdy szatą myśli, która sama byłaby sobie dostępna bez żadnych niejasności", jest raczej ich dopełnieniem, z tym wszak zastrzeżeniem, że często mówiąc, sami nie wiemy, co wyrażamy nie bardziej niż ci, którzy nas słuchają (tamże: 33, 168). Języka nie da się tylko sprowadzić do jego powiązania z myśleniem i ująć go wedle kryteriów intelektu10. Istnieje przedjęzykowe rozumienie

8 Z perspektywy psychologii kultury w życiu osoby dorosłej myślenie obrazowo-symboliczne (a w zasadzie metaforyczno-symboliczne) istnieje obok myślenia werbalno-pojęciowego (intelektualnego) (Dudek 2005: 245-252). Opiera się ono na nielinearnym i polichronicznym, symbolicznym i bezpośrednim (intuicyjnym) odbiorze rzeczywistości. Myślenie werbalno-pojęciowe z kolei opiera się na linearności, monochromiczności, selekcji, transformacji, asymilacji i integracji napływających do człowieka informacji. Język metaforyczno-symboliczny uaktywnia się przede wszystkim w kontakcie ze sztuką i religią, jak również w wyobraźni, w fantazjach i w marzeniach. Jest ważny w rozwoju kultury duchowej człowieka - to posługiwanie się nim oznacza przesunięcie aktywności mentalnej w „głąb siebie” przy jednoczesnej aktywności ukierunkowanej za zewnątrz siebie. Język horyzontalny jest językiem konwencjonalnym, opartym na dominacji w świadomym myśleniu słów i pojęć, organizuje on podstawową przestrzeń wymiany społecznej, będąc zarazem warunkiem społecznej adaptacji. W rozwoju człowieka jest to język wtórny, ponieważ zostaje przejęty od otoczenia zewnętrznego. Myślenie werbalno-pojęciowe i jego język tworzy zewnętrzną warstwę osobowości, ukierunkowując życie psychiczne w stronę społeczności, zbiorowości, akcentując konwencjonalne wartości zbiorowe. Kiedy zatem mówimy o języku, warto mieć na uwadze te dwa jego rodzaje, choć zazwyczaj w odpowiedzi na pytanie „czym jest język?” przychylamy się do wskazania na język horyzontalny, charakterystyczny dla myślenia werbalno-pojęciowego. Por. także B. Andrzejewski (2016).

9 Zdaniem Merleau-Ponty nie da się podtrzymać następującego założenia: „[...] rozumiem, co do mnie mówią, właśnie dlatego, że z góry znam sens owych słów, które do mnie kierują, i ostatecznie rozumiem tylko to, co już sam wiedziałem, i nie stawiam sobie innych problemów niż te, które mogę rozwiązać" (1999: 44). Takie podejście do języka raczej zakłada ograniczenie mojej percepcji Drugiego.

${ }^{10}$ W późnej twórczości Ludwika Wittgensteina, w dziele Dociekania Filozoficzne, jednym z kluczowych rozważań jest kategoria gier językowych, która odsłania myślenie także w znaczeniu pozawerbalnej i niedyskursywnej czynności, czasami także aporetycznej i paradoksalnej. Człowiek najczęściej myśli za pomocą języka, ale może myśleć także za pomocą obrazów, dźwięków, wyobrażeń, odległych skojarzeń. I choć przywykliśmy do myślenia jako czynności jasnej, uporządkowanej, ukierunkowanej, analizującej i odkrywającej coś przed nami, to Wittgenstein mówi także o prawomocności, np. myśli pojawiającej się w okamgnieniu, niespodziewanie, zanim przybierze jakikolwiek wyraz (2000: 320- 
przez ciało-podmiot, a myśl jako element świadomości refleksyjnej pojawia się wraz z językiem rozumianym jako „mowa mówiona”/„mowa wysławiana” (parole parlee), w której manifestuje się to, co przynależy i określa wspólną perspektywę intersubiektywności w podmiocie, ale co nie da sprowadzić się do samego podmiotu i jego przeżyćc11. Znaczenia są już ukonstytuowane w mowie, a w zasadzie ją poprzedzają, ale też po niej pozostają jako coś danego jakby do kolejnej konsumpcji słów. Dlatego zostaje także wyróżniona przez Merleau-Ponty repetycji - powtarzaniu i potwierdzaniu zastanych znaczeń. Słowa, zanim wybrzmią nowymi znaczeniami, zanim się ucieleśnią, zanurzone są w pierwotnej łączności człowieka ze światem o charakterze pozajęzykowym (Merleau-Ponty 2001: 160-218). Łączność ta jest milcząca, dopiero cielesna ekspresja słowa, zaczynająca się jeszcze na bezdechu, w otwarciu ust i w heideggerowskim „okamgnieniu” - w rodzącej życie szczelinie bytu - wprowadza człowieka w „mowę mówioną”. Wówczas mowa wybrzmiewa znaczeniami „na równi dzięki temu, czego nie mówi, jak dzięki temu, co mówi”12 (Merleau-Ponty 1999: 46). Samo słowo - jako gest językowy - odsłania modulację ekspresji własnej egzystencji i przestaje znaczyć to, co literalnie znaczy - „tak że lada wahanie, lada odmiana głosu, dobór pewnej składni wystarczą do jego modyfikacji" (tamże: 164-165). W ten sposób słowo wykracza ponad wspólnie ustanowione i nabyte znaczenie - wykracza ku swojemu znaczeniu, którego wcześniej nie posiadało - ku znaczeniu, które „dopiero ma się zjawić” (tamże: 163). To ciążenie mowy na zewnątrz, to wyrażanie siebie wobec Drugiego/Drugich - wypowiadanie siebie (dla siebie), a zarazem wobec Drugiego/Drugich - również na drodze przyswajania sobie ich mowy i za jej pośrednictwem.

Słowa nie są zatem prostymi (o)znaczeniami czegoś/kogoś - są nośnikami (o)znaczeń jako „nieredukowalnych fenomenów” i choć zazwyczaj daje się je sprowadzić do „obrazu dźwiękowego”13 lub wyrazu jako graficznego zapisu, to ich ważność ujawnia się wówczas, gdy „zwracamy się ku znaczeniu, a nie ku samemu językowi" (Jaspers 1990: 199)14. W spotkaniu jednego człowieka z Drugim - stanię-

335). Por. o różnych modi myślenia pisze także Barbara Skarga w eseju pt. Co zwie się myśleniem (2004: 106-135).

${ }^{11}$ Barbara Skarga, w sporze z Derridą, zauważa, że - owszem - nie da się podważyć językowego charakteru świata, żyjemy w języku, w przyjętych i uznanych jego znaczeniach, i poddajemy się mimowolnie i świadomie jego wpływom kształtującym „nasz” język. Ale z drugiej strony należy przyznać znaczące miejsce przeżyciom przeddyskursywnym. Gdyby tych przeżyć nie było, nasze myślenie odbywałoby się w spektrum uniwersum, jakie stworzyła społeczność, w której żyjemy - a wówczas zniknęłaby inność mnie myślącego, Ciebie myślącego i inność mowy. Człowiek wówczas nie potrzebowałby Drugiego, bo z góry mógłby przewidzieć, w jakim języku myśli i mówi i jakie nadane są temu znaczenia - a wtedy „Indywidualny sens roztopiłby się w tym, co rozpowszechnione” (Skarga 2004: 21).

${ }^{12}$ Merleau-Ponty powie: „włókna milczenia wplecione są w tkankę słowa” (1999: 156). Do tego wątku powrócę nieco dalej.

${ }^{13}$ Określenie użyte przez Gustava Gerbera i przytoczone przez Karla Jaspersa (1990: 200).

${ }^{14}$ Jasper wymienia dwa podstawowe rodzaje znaczenia, będące środkiem języka - niezamierzone, które są tym, „co zjawia się w przestrzeni i czasie i, ma pewien wyraz, który dostrzegamy mimowolnie” i rozmyślnie utworzone, rozumiane jako „dzieło, wytwór, przedstawienie. (...) Wszystkie te wytwory rozumiemy dopiero w ich użyciu” (1990: 197). 
ciem wobec Jego twarzy - szczególnego znaczenia nabierają słowa żywe - słowa jako „obrazy dźwiękowe”, które - zdaniem Jaspersa - „przeniknięte są od początku pewną atmosferą, mają głębię i tło, a stąd i wagę. (...) Nigdy nie przybierając ostatecznej postaci, są życiem przekształcających się znaczeń. (...) żyją z bogactwa swego tła”, a ich treść współbrzmi z nastrojem (tamże: 204-207). W słowie żywym pozostaje jakaś reszta - jakieś niewybrzmienie, które zaprasza do skierowania uwagi na tego, który słyszy/słucha i tego, który mówi - czy Mówiąc?

\title{
Wy-brzmienie Powiedzianego i Niepowiedziane - poezja intersubiektywności
}

\author{
(...) znaczenie nigdy nie tkwi bez reszty w słowie, \\ każda ekspresja zawsze wydaje mi się podobna do śladu, (...) \\ wszelkie staranie się, by schwytać w garść myśl przebywającą w słowie, \\ zostawia w palcach jedynie odrobinę słownego tworzywa.
}

(Merleau-Ponty 1999: 164-165)

W sferze intersubiektywnej posługiwanie się słowami stanowi żywą mowę - mowę cielesną, w tym znaczeniu, że słyszalną w wypowiadanym słowie. Słowo - w pełni dźwiękowej cielesności - występuje jako głos. Ten cielesny aspekt mowy - zaledwie ulotna wibracja wydychanego powietrza tego, który mówi - jest słyszalny. Cielesność słowa, „słyszalna namacalność” to jego dźwięk, tempo, rytm, dynamika, natężenie, intonacja, modulacja, frazowanie, barwa et cetera i już nie tylko pojedynczego słowa, choć w nim zaklęcie. Za sprawą różnych sposobów modulacji głosu, mowa opalizuje znaczeniami wypowiadanych słów, a to dlatego, że to właśnie „mój głos łączy się z całością mojego życia tak, jak nie czyni tego żaden inny głos”, to słowa wybrzmiałe znaczeniami dla wypowiadającego i dla słuchacza (Merleau-Ponty 1996b: 148)15. Poprzez wibrację słowa - jego muzyczność - tworzy się architektonika mowy jako niezbywalny warunek konstytucji spotkania jednego człowieka z Drugim ${ }^{16}$.

\footnotetext{
${ }^{15} \mathrm{Z}$ głosem współpracują środki przekazu wykorzystujące inne kanały komunikacji: gest i mimika, pozycja ciała i ruch, a także ubiór, zwane mową ciała. Walter J. Ong pisał: „Ruchy ciała towarzyszące wokalizacji nie są w komunikacji oralnej przypadkiem lub wymysłem, są naturalne, a nawet - nieuchronne" (tenże za: Zając-Jamróz 2012: 57). Osobnych studiów wymaga tylko sygnalizowany w tym miejscu wątek o związku ciała i słowa, począwszy chociażby od ujęcia cielesności przez Merleau-Ponty.

${ }^{16}$ Również dla Jacquesa Derridy mowa wyrażona głosem jest postacią uobecniania się człowieka samemu sobie i innym - za pośrednictwem głosu wkracza w sferę intersubiektywną (1997: 170-180). Wypada w tym miejscu odnotować za Joanną Michalik: „«Słowo żywe» interesuje Derridę niemal wyłącznie w perspektywie transcendentalnej wczesnej fenomenologii Husserla, sprowadzone do «głosu fenomenologicznego», zredukowane o jego zmysłowy aspekt, pozostaje żywiołem «metafizyki obecności»" (2010: 197; 2011: 108). Dla Derridy podstawą wykroczenia poza fonologocentryczną metafizykę stanowi pismo.
} 
Dla Jaspersa znaczenia słów ujawniają się dopiero w dynamice zdań, odsłaniającej ich sens, ale zarazem słowa nieumieszczone jeszcze w zdaniu, ale wybrzmiałe, mogą budzić emocje i porywać (Jaspers 1990: 214) - „Słowa jako takie - powie nie mają bowiem żadnego ostatecznego, żadnego jedynie słusznego sensu - nadaje im dopiero użycie" (tamże: 248). Ale nie chodzi tylko o proste ich użycie - o ich dźwiękowe wybrzmienie. One są kierowane do Drugiego i jako takie mogą być właściwie lub niewłaściwie dobrane i wysłowione, mogą wyrażać autentyczność bycia tego, które je wypowiada lub być tylko zewnętrzną jego dekoracją. Żywe słowa to zarówno słowa pospolite, jak i odświętne, a i też jedne i drugie stają się często słowami wyświechtanymi - bez znaczenia dla mówiącego, ale czy dla tego, do którego są skierowane? Żywe słowa - a zatem słowa użyte - uruchamiają w tym, który je słyszy, zróżnicowaną gamę emocjonalnych doznań, rozpiętą od przykrości, smutku, rozdarcia et cetera do przyjemności, wesołości, spokoju et cetera.

Mowa w swej ekspresji jest medium możliwego po-rozumienia w spotkaniu między jednym człowiekiem i Drugim. Po-rozumienie dopiero wytwarza się jako sztuka użycia słów w mowie. Ekspresja słowa - choćby miałaby wyrazić się w dziecięcym smakowaniu nieartykułowanych dźwięków sylab, słów, fraz - jest sztuką wyjścia poza znaczeniowość słowa ku jego wy-brzmieniu - ku Drugiemu. Czy mówiąc, można milczeć? ${ }^{17}$ Czy milcząc, można dać znak Drugiemu?

Gadamer mówi o „wirtualności słowa”, które po odpadzie powszechnych znaczeń wykracza ponad to, co wypowiada/co może wypowiadać (Gadamer 2008: 122-123). Dokąd zmierza? Ku milczeniu - ku temu, gdzie nie ma wypowiedzianego słowa. Na drodze ku milczeniu słowo zawisło zanim zostało wypowiedziane, zanim stało się dźwiękiem. Wówczas można posłyszeć „głosy ciszy”, które milcząc, odsłaniają i wyłaniają - jak dla Merleau-Ponty - potencję mówienia.

Milczenie - jak sugeruje interpretować rozważania Platona o mowie Wodziński - nie leży po drugiej stronie granicy z mową, lecz jest drugą, w pełni prawowitą jej stroną (Wodziński 2008: 103-104). To mowa zakłada już umiejętność stosownego milczenia, ponieważ sama jest bliska milczeniu. Milczenie i mowa są odbiciem tego, co w różnym stopniu jest niewypowiedziane. Mowa milczenia „zapowiada i doprowadza do granicy niewypowiadanego”, za którą skrywa się milczenie, lub w której to granicy milczenie bytuje (tamże: 107). Heidegger powiada, że język „mówi” jako „bezgłośny pogłos ciszy” (Heidegger 2000: 198). Cisza, przynależąc do Powiadanego, przenika je - obejmuje je, tak jak nicość obejmuje byt. Pogłos ciszy korespondujący z ludzkim milczeniem może być bardziej powiadający niż mowa.

\footnotetext{
${ }^{17}$ Por. Merleau-Ponty pisze: „To, że uważamy zawsze za model słowa twierdzenie albo zdanie oznajmujące, przesłania nam żywy związek osób mówiących, a czynimy tak, gdyż sądzimy, że poza twierdzeniem jest tylko bełkot i niedorzeczność" (1999: 77).
} 
Milczenie może mieć wiele znaczeń. Dla Jaspersa z jednej strony jest zamierzone, a z drugiej jest niemotą utożsamianą z autentyczną egzystencjalną komunikacją (Jaspers 1999: 140-141). Milczenie zamierzone jest tylko pośrednią formą komunikacji, w której nie pozostaje się otwartym w stosunku do Drugiego i nie jest się gotowym na jego przyjęcie. To milczenie zapowiadać może jedną z postaci ciszy wyróżnianych przez Jacka Filka - ciszę złowróżbną, a nawet destrukcyjną, która rozpoczyna się wraz z przedłużającą się pauzą w mówieniu, rodzącą niepokój (Filk 2014: 90). Ale cisza i obecne w niej nie-mówienie/milczenie może otwierać drogę ku Drugiemu - staje się warunkiem (u)słyszenia Drugiego, a także (u)słyszenia siebie - swego głosu wewnętrznego, który „milczy, a jednak przemawia” - pozywa mnie ku sobie samemu (tamże: 93) ${ }^{18}$. Milczeć można także w dialogu - taką postać ciszy Filek określa wewnętrzną ciszą dialogiczną, która jest miejscem spotkania i w której „potrafimy usłyszeć głos wewnętrzny drugiego człowieka” (tamże: 94) ${ }^{19}$.

Wymowne stają w tym miejscu słowa Jaspersa:

Mowa spełnia się w milczeniu. (...) W trakcie komunikacji językowej milczenie staje się pewną formą mówienia. Milczenie to nie jest przemilczaniem czegoś, co wiem i co mógłbym powiedzieć. Przeciwnie, jest ono - wobec innych wzajemnie ze mną myślących, wobec mnie samego i wobec transcendencji - milczeniem wypełnionym u granic wyrażalności. Milczenie to nie jest niemą bezmownością, która niczego nie mówi, a zatem również milczy (Jaspers 1999: 244).

Milczenie samo nie jest zatem brakiem słów. Milczy się wtedy, gdy zarazem można mówić. Milczenie mówi i jego mówienie odsłania wiele znaczeń - milczenie jest zatem znaczące i znaczy. Merleau-Ponty powie: „milczenie w rzeczywistości szumi słowami; to wewnętrzne życie jest wewnętrzną mową" (Merleau-Ponty 1999: 93) - nieśpieszną, nieposzukującą słów, a słowa odnajdującą, ich celebracją i zapomnieniem, ich ulotnością znaczeń i ich krystalizacją.

Być może, aby móc usłyszeć słowo, które „waży”, potrzeba nam także nauczyć się milczenia.

\footnotetext{
${ }^{18}$ Filek mówi o ciszy „wewnętrznego zmysłu słuchu”, która „jest przeciwieństwem zgiełku myśli, rwetesu pragnień, szarpaniny uczuć" (2014: 94). W takiej ciszy milczenie jest kojące.

${ }^{19}$ Spotkaniu ze sobą i milczeniu dialogicznemu sprzyja nie tylko cisza zewnętrzna, ale także ta, którą odnajdujemy w sobie jako ciszę wewnętrzną. W tym miejscu chcę zasygnalizować tylko pewną wątpliwość w możliwość usłyszenia głosu wewnętrznego Drugiego. Po pierwsze dlatego, że Drugi sam może takim głosem „nie przemawiać” w tym znaczeniu, że nie ma do niego dostępu, po drugie dlatego, że jeśli nawet ów głos w naszym mniemaniu posłyszymy, to nie będziemy dysponowali „instrumentarium” jego rozumienia. Por. Krzysztof Mech, prezentując projekt hermeneutyki Innego, pyta: „[...] w jaki sposób, mówiąc, mogę wkroczyć w wewnętrzną logikę mowy Drugiego, we wzajemny związek zawartych w niej znaczeń, skoro moja mowa wydarza się w ramach radykalnie odmiennego kontekstu niż jego?" (2014: 53). Równie ważnym w tym miejscu wydaje się inne pytanie: Co wydarza się między mową Drugiego a moją zdolnością odczytu i przyswojenia oraz (z)rozumienia jej znaczeń?
} 


\section{Kto mówi - również milcząc?}

Cóż więc wyraża mowa, jeśli nie wyraża myśli?
Otóż przedstawia ona pozycję
lub raczej jest zajęciem pozycji podmiotu w świecie jego znaczeń.
$(. .$.$) Fonetyczny gest urzeczywistnia$
- zarówno dla mówiącego, jak i dla słuchającego
- pewną strukturę przeżycia, pewną modulację istnienia (...).

(Merleau-Ponty 1999: 109)

Paul Ricoeur wskazał na kilka rodzajów słów, które odsłaniają przede wszystkim tego, kto mówi w jego relacji do siebie samego, do Drugiego i świata (Ricoeur 1991: 95-97). Słowo rozkazujące wyznacza kierunek działań i emocjonalnych nastawień wobec siebie samego - w słowie tym Ja stanowi o sobie, kładąc kres uczuciowym wątpliwościom. Ono sprawia, że już nie tylko myśli się „o”, lecz także podejmuje się działanie. Kolejnym rodzajem słowa jest słowo orzekające, w którym oświadczam sobie i innym, kim jestem. Natomiast za pośrednictwem słowa lirycznego wyraża się własne uczucia. Słowo wyrażające życzenie jest słowem, za pośrednictwem którego zwracam się do siebie i Drugiego, odsłaniając projekt samego siebie, jak również projekt bycia z Drugim wynikający z nieobojętności (lub obojętności) na siebie i Drugiego. Dla Ricoeura ważnym było także słowo wątpiące chroniące nasze rozumienie (bycie) przed skostnieniem i otwierające możliwość rozumienia (bycia) inaczej - „Słowo wątpiące pyta: co to jest?, co to znaczy? (...) burzy porządek znaczeń (...) wprowadza wymiar możliwości. (...) ujmuje sens rzeczywistości (...) wychodząc od sensu możliwego" (tamże: 97).

Nawet najbardziej precyzyjnie dobrane słowa, ujęte w wypowiedź mają charakter od-autorski, czyli najbardziej ich sens jest bliski (nie zawsze jasny) temu, kto je wypowiada. W tym miejscu warto zwrócić uwagę za Gadamerem na źródło słowa - onoma, które oprócz nazwy czegoś oznacza również nazwę własną i imię. Słowo jako imię wskazuje zawsze na jego właściciela, ono samo dopiero jest czymś, przez to, że ktoś je nosi. „Należy ono - pisze Gadamer - jak gdyby do bytu swego właściciela", ten kto mówi jest w swoim słowie bezpośrednio obecny (Gadamer 1993: 371). Wsłuchując się w wypowiadane słowa i odkrywając ich znaczenie oraz odkrywając, jak wy-brzmiewa milczenie tego, który już/jeszcze nie mówi, dochodzimy również do ujawnienia sobie tego, kto mówi/kto milczy.

Dla Merleau-Ponty mowa ma „znaczenie egzystencyjne” - to w niej i poprzez nią człowiek rzutuje siebie ku światu (Merleau-Ponty 1999: 99). Człowiek wypowiada siebie za pomocą znaczeń, którymi rozporządza i znaczeń, które buduje, określając w ten sposób swój sposób życia. I wypowiada siebie, milcząc. I właśnie owo „znaczenie egzystencyjne” wskazuje na źródło mowy - na to, że „ktoś mówi coś do kogoś o czymś”. „Kto” mówi, ujawnia się wraz z napotkaną lévinasowską twarzą Drugiego, która „prześladuje mnie w swej nędzy i ogołoceniu. «Patrzy na mnie», wszystko w niej dotyczy mnie, nic nie jest mi obojętne" (Lévinas 2000: 157). 
Znaczenie twarzy, choć odsłania się w źródłowej mowie Drugiego, a może raczej jest źródłem jego mowy, rodzi się poza intencją Drugiego - rodzi się we mnie. Dlatego mówienie jest zawsze czyjeś - do kogoś przynależy. Mowa/mówienie nie jest jednak narzędziem służącym do eksterioryzacji siebie - uzewnętrzniania siebie choćby w dialektyce jawności i skrywania. Etyczny nakaz, który przychodzi od Drugiego - o czym mówi filozofia Innego Lévinasa, domaga się mojej odpowiedzi. „Ruch” wychodzący od niego domaga się mojego „ruchu”, skierowanego w jego stronę. Ukierunkowując się na Drugiego, mówiący, choćby milcząc, ujawnia siebie. To ujawnienie siebie - swojego bycia w świecie - to ujawnienie siebie jako podmiotowości, która „ciągnie za sobą swoje ciało” (Merleau-Ponty 2001: 375). Dopiero jednak wspólna mowa, będąca przejawem ucieleśnionego bycia-w-świecie każdego z mówiących ${ }^{20}$, „odbiera naszemu istnieniu gęstość absolutnego i jedynego aktu”, przypomina „anonimową cielesność” będącą „wspólną sytuacją, która jest nie tylko wspólnotą istnienia, ale również wspólnotą działania” (tamże: 71-72). Ten, kto mówi do Drugiego, nie może mówić bez tego, który nie tyle go słyszy, co również zwraca się do niego, ucieleśniając swoje bycie-w-świecie. W tym, kto mówi do kogo, odkrywa się jakieś zachodzące między nimi podobieństwo, które stępia różnicę między nimi. Kto mówi, rozpoznaje w tym, do kogo mówi nie swoje alter ego, ale pokrewieństwo egzystencjalne i dzięki temu rozpoznaniu może powiedzieć: „To ty - taki jak ja, ale zarazem Drugi".

W istocie słowa skrywa się to, co ono daje - „O słowie przeto, myśląc dorzecznie, nie możemy powiedzieć: jest (Es ist), lecz: daje (Es gibt). (...) słowo daje: bycie" (Heidegger 2000: 143). Za pośrednictwem słowa wy-powiadanego/wy-powiedzianego do Drugiego i słowa milczącego/przemilczanego w jego obecności, docieramy tam, skąd już jesteśmy pozwani - do bliskości z Nim jeszcze bez znaczenia jej samej. Słowo skierowane do Ciebie wskazuje na mnie - jest wieścią dla Ciebie ode mnie.

\section{Mówiący dorosły i (nie)mówiące dziecko}

Słowo (...) rozpoczyna się na nowo wraz z każdym dzieckiem.

(Merleau-Ponty 1999: 152)

Kim jest małe dziecko dla dorosłego? Kiedy małe dziecko pojawia się w polu percepcyjnym dorosłego, ten doświadcza spotkania z nim mniej lub bardziej bezpośrednio. Dorosły w tym spotkaniu jest mniej lub bardziej obecny w zależności od wielości jego kontekstów, wartościowań dorosłego, jego uczuć, wcześniejszych

\footnotetext{
${ }^{20}$ Dla Heideggera czy Merleau-Ponty podmiot i świat są konstytutywnie powiązane ze sobą. Merleau-Ponty pisze: „Świat nie daje się oddzielić od podmiotu, ale od podmiotu, który nie jest niczym innym niż projektem świata, a podmiot nie jest nieodłączny od świata, ale od świata, który on sam projektuje" (2001: 451).
} 
doświadczeń i towarzyszących spotkaniu intencji, jak i zainteresowania małym dzieckiem jako podmiotu/przedmiotu spostrzeżenia i widzenia dorosłego (por. Merleau-Ponty 2001: 29)21. Czy pytanie: „Kim jesteś dla mnie Ty jako to oto małe dziecko?" zrodziło się z ciekawości, niepokoju, obawy, lęku, zaintrygowania, wątpliwości, interesu et cetera? Czy dorosły w ogóle stawia sobie takie pytanie?

Małemu dziecku w życiu codziennym - podobnie jak dorosłemu, o czym przekonuje nas fenomenologiczne ujęcie percepcji - życie (świat) jest dane w sposób konkretny, zmysłowy czy naoczny. Dziecko, przeżywając życie, poznaje je, dla dorosłego przeżywanie życia jest podstawą i warunkiem jego konceptualizacji i artykulacji za pomocą języka pojęć. Czy w tematyzacji życia tego oto małego dziecka i jego przejawów jak i zapowiedzi dorosły nie dokonuje przywłaszczenia sobie z góry znanych znaczeń tego życia? Czy zawsze małe dziecko, którego poznanie (a zatem i tematyzacja) jest projekcją uprzedniego poznania (uprzedniej tematyzacji) - odtworzeniem danego dorosłemu już wcześniej poznania? Czy mówiąc do małego dziecka, dorosły nie mówi jednak do stematyzowanej już postaci tego oto dziecka?

Jak to oto małe dziecko i jego mowa jawi się dorosłemu i czym jest owo doświadczenie jawienia się dla dorosłego? Pierwsze pytanie odnosi się do małego dziecka jako własności istniejącej w świecie, drugie natomiast do własności doświadczenia dorosłego - do tego, czego dotyczy i czym jest dla niego i co tym samym odsłania jego intencjonalność. Pozostając w kręgu fenomenologicznym - intencjonalność ujmę jako niezbędną własność świadomości jako świadomości czegoś/kogoś lub czegoś/kogoś dotyczącą, odsłaniającą pierwszoosobową obecność doświadczenia - „mojość”/„swojość” strumienia przeżyć zależną od percepcji świata, jak również i to, kim jest dorosły - jako kto on sam sobie prezentuje się i czym jest jego ukierunkowanie się na siebie i świat zewnętrzny - na małe dziec$\mathrm{ko}^{22}$. Intencjonalna relacja dorosłego $\mathrm{z}$ małym dzieckiem determinuje jawienie się dorosłemu małego dziecka i jego mowy. Intencjonalność dorosłego znajduje się już w samej percepcji małego dziecka i będzie „rzutować” na ujmowanie dziecka i jego mowy nawet wówczas, gdy „wyniki” tej percepcji są błędne, iluzoryczne, złudne et cetera (por. Heidegger 2009: 64-65).

W spotkaniu z małym dzieckiem - także mimowolnie - dochodzi do głosu tematyzująca go aktywność dorosłego. Dorosły, wypowiadając się o nim, wnosi do

\footnotetext{
${ }^{21}$ Por. w psychologii i pedagogice Gestalt zasada postaci mówi o tym, że na percepcję poszczególnych cech, wymiarów, aspektów postaci wpływa cały kontekst, w którym postać ta jest zanurzona - obecna. Por. o znaczeniu percepcji pacjenta przez terapeutę z perspektywy psychologii egzystencjalnej pisze Małgorzata Opoczyńska w rozdziale pt. Co mówi oko, pokazując język? Widoki, powidoki i zmyśleni (2016: 193-216). Wiele poruszanych przez Opoczyńską wątków kapitalnie koresponduje z problematyką niniejszego artykułu, stając się także inspiracją dla mnie. Osobnego opracowania wymaga znaczenie percepcji wzrokowej w relacji dorosły - małe dziecko, która jest równie ważna dla jakości tej relacji, jak obecna w niej „praca słowa” i milczenie.

22 Por. S. Gallagher, D. Zahavi (2015) rozdziały pt. Świadomość i samoświadomość (s. 68-101) oraz Intencjonalność (s. 160-191).
} 
przestrzeni obcowania z nim jakieś domknięcie, zawęża perspektywę jego pojmowalności. Tematyzacja prowadzi do oswojenia i udomowienia - jest objaśnieniem sobie - dorosłemu - małego dziecka, a słowa użyte w tym celu zdają się go zawierać - ono staje się/jest tematem wypowiedzi dorosłego. W gęstości tego, co wysławiane - tego, co Powiedziane o małym dziecku - ginie ten, który jest „pierwszym przybyłym”, niezapowiedzianym „pierwszym gościem”, wymakającym się „wszelkiej istocie, gatunkowi, podobieństwu" (Lévinas 2000: 145). I to jest stanowisko Lévinasa, który wyraża je w obawie przed uprzedmiatawiającą siłą mowy nieróżnicującej - mogę mówić o przedmiotach i w taki sam sposób o ludziach i innych żywych stworzeniach. Co może sprawić, aby wypowiedź o małym dziecku, które jest Drugim, prowadząca zdaniem Lévinasa do wiedzy o nim, nie musiała oznaczać zdrady dorosłego wobec małego dziecka wraz z próbą uprzedmiatawiającej go tematyzacji ${ }^{23}$ ?

Partykularność poznania i zbudowanej na nim lub przyjętej wcześniej wiedzy, również partykularnej, a zatem stanowiącej ledwie przesłankę do formułowania przypuszczeń, wymaga w spotkaniu z tym oto małym dzieckiem - „uważnej obecności”, która źródłowo zasadza się na troszczeniu się o jakość swojego bycia z Drugim ${ }^{24}$. Troska zaś jest odpowiedzią na spotkanie z jego Twarzą, na to, co małe dziecko jako Drugi mówi do dorosłego, również milcząc. I idąc po lévinasowskich śladach, to w odpowiadaniu na wołanie małego dziecka jako Drugiego jako języku słuchania, u źródeł którego jest spotkanie z jego Twarzą - odnajdujemy etyczną istotę języka istoczącą się wraz z pierwszym wybrzmiałym w skrytości pytaniem „jak mam być z Tobą?"25. Czy poznając małe dziecko w aktach percepcji, myśląc o nim i wypowiadając się o nim, dorosły stara się go zrozumieć? A rozumienie, o czym przekonuje nas chociażby gadamerowska hermeneutyka, to nie wiedza o kimś. Rozumieć to przejąć się tym, kto do mnie mówi i kto domaga się ode mnie odpowiedzi, otworzyć się na to, co jest różne ode mnie i tę różnicę uszanować i jednocześnie zadbać o jej niepogłębianie. Rozumienie jest krokiem ku możliwej wspólnocie etycznej, ufundowanej na bliskości w różnicy. Znosi ono śmiałość tematyzacji i otwiera przestrzeń pierwotnego Mówienia.

Drugi objawia się temu, który do niego mówi w autoekspresji, a jak powiedział Merleau-Ponty „gesty ekspresji (...) stanowią pierwszą mowę”, wskazują na mówiącego jako na ich źródło (Merleau-Ponty 1999: 32). Słowo jest jednym z gestów, wtórnym do „gestykulacji emocjonalnej” jako „naturalnych znaków”, w której należy szukać „pierwszych zarysów mowy” jako sposobu bycia ludzi w świecie - jako tego, co ich łączy i jak ze sobą są (tamże: 101). Zatem mowa dla niego jest wielością różnicujących i przecinających się ze sobą gestów, które mają postać

\footnotetext{
${ }^{23}$ Próbę odpowiedzi na tak wybrzmiałe pytanie podejmuje Krzysztof Mech w swoim projekcie hermeneutyki Innego w kontekście rozważań Lévinasa (2014: 31-52).

${ }^{24}$ Szerzej pisałam o tym w artykule: Etyka (w) codzienności wychowania - od nieuchronności do możliwości (Walczak 2016).

${ }^{25}$ Lévinas powie: „Epifania twarzy jest etyką” (1998: 234).
} 
pierwotnych i wtórnych znaków i których znaczenia wykraczają poza nie. Tym bardziej, że słowo będące jakimś dźwiękiem lub widzialnym układem znaków graficznych jest zarazem „tylko dźwiękiem płynącym w powietrzu lub śladem muszych łapek na papierze" (tamże: 43). Ten, który się wypowiada wyłącznie za pomocą języka skodyfikowanego, w którym jako dorosły żyje i dla którego słowo znaczy to, co znaczy, skrywa się za zasłoną swojego języka - pozostaje dla małego dziecka niedostępny. Mowa małego dziecka jest inna i nie chodzi tylko o to, że dziecko wkracza dopiero w język dorosłego, ale o to, że wychodzi ku dorosłemu z zapomnianego przez dorosłego języka niespekulatywnego. Języka emocji i percepcji niewyrażanych konwencjonalnym słowem, który jeśli nie jest zapomniany przez dorosłego, bo być nie może, to nie jest jego głównym językiem w ekspresji siebie i porozumiewaniu się z małym dzieckiem. Jeśli ich języki są nieprzekładalne, oznaczałoby nie tylko niezdolność pojmowania odmiennych światów znaczeń, ale także niemożność odnalezienia bliskości bycia (w byciu ze sobą), której nie niszczyłyby różnice pomiędzy ich językami. Czy na pewno? Psychologia rozwojowa poucza nas, że dziecko przyswaja sobie język dorosłego - znaczenie kierowanych do niego słów - około 2 roku życia. Jak już twierdził Merleau-Ponty, dokonuje się to znacznie wcześniej - jeszcze zanim zacznie ono mówić (a nawet już w okresie prenatalnym). Język - „styl ekspresji” dorosłego - narzuca się małemu dziecku, jest w niego wciągnięty jak w wir - od antycypacji fonetycznych jego aspektów aż po moment, „gdy cały ten hałas zaczyna coś oznaczać” (Merleau-Ponty 1996: 112). Małe dziecko jest już otoczone językiem - osobami, które jeśli nawet do niego nie mówią lub nie mówią często, to mówią do siebie i do innych ${ }^{26}$. Wszędzie wybrzmiewa głos dorosłego, który jest jego nośnikiem mowy, odsłaniając „emocjonalny sens słowa”, zwany przez Merleau-Ponty „sensem tekstowym” (Merleau-Ponty 2001: 209). Małe dziecko słyszy i odbiera znaczenia wieloaspektowości głosu - jego barwę, intonację, melodię, wysokość, głośność i cichość, załamanie i pewność, płynność i brak płynności, skrywanie czegoś i ujawnianie, jego ciepło i chłód et cetera.

Paweł Dehnel, analizując późną filozofię Ludwika Wittgensteina, zauważa za nim, że użycie słów, które wyznacza ich znaczenia

jest częścią ludzkiej aktywności, pewnego sposobu życia (Lebensform), który składa się na naszą historię naturalną. (...) Dziecko nie uczy się najpierw znaczenia słowa „rozkazywać” nim zacznie je stosować, czyli zanim zacznie po prostu rozkazywać; nie uczy się przekładania swoich myśli na słowa, po prostu uczy się rozkazywać, pytać, opowiadać, wołać, prosić, odpowiadać na pytania etc., tak samo, jak uczy się chodzić, bawić się, prosić, wołać, pić i jeść (Dehnel 2016: 278).

\footnotetext{
${ }^{26}$ Osobnych studiów analitycznych wymagałby problem relacji dorosłego z małym dzieckiem niesłyszącym lub niedosłyszącym, ale również relacji dorosłego niesłyszącego lub niedosłyszącego i małego dziecka, które słyszy.
} 
Idąc tym tropem należy stwierdzić - małe dziecko uczy się znaczeń słów w kontekście działań splecionych z różnymi sposobami życia ${ }^{27}$ i ulokowanych w różnych konfiguracjach kulturowych, a to oznacza, że dane słowo znaczy też na wiele sposobów, w zależności od tego, w jakim kontekście jest ono używane. A uczy się tego na początku, podpatrując i podsłuchując dorosłego oraz słysząc i słuchając, co dorosły mówi do niego ${ }^{28}$. Małe dziecko zaczyna zatem mówić w tym języku, w jakim przede wszystkim żyje dorosły. Jest to język żywy - w nim się mówi, a nie o nim się mówi, o tym, jak działa według określonych reguł. I jeśli Wittgenstein mówił o grach językowych, to one same nie ograniczały się do problemu reguł i ich przestrzegania. Języka jako jednej z form aktywności ludzkiej nie da się ograniczyć do aktywności kierowanej regułami, które zamykają się w normatywnych praktykach wyjaśniania znaczeń i ich stosowania. Podobnie jak z myśleniem, zauważa Wittgenstein, użycie słów - mówienie - nie jest czymś, nad czym się zastanawiamy, kiedy słów używamy - kiedy mówimy. Dopiero kiedy myślimy o języku jako czynności operującej znakami, wówczas chcemy go wyjaśnić, dotrzeć do jego istoty, do tego, czym jest. Małe dziecko mówi - mówi do dorosłego, a jego zdolność mówienia określić można jako protojęzykową ${ }^{29}$. W nawiązaniu relacji z małym dzieckiem, o której mówił Lévinas jako Mówieniu, ważne staje się zatem nie tyle uczenie dziecka języka dorosłego - ono samo się go uczy, a posłyszenie, wsłuchanie się w jego język - w jego mowę i umiejętne od-powiedzenie mu.

Obecność słowa nie jest czymś, o co chodzi w wychowaniu rozumianym jako intersubiektywność w czaso-przestrzeni, jest ona okazją, która nadaje znaczenie tej intersubiektywności - już wtórnej, bo pierwotna obywa się bez słowa. Nie chodzi jednak o samo słowo jako takie, lecz przede wszystkim o mówienie i jego „choreografię" - formowanie i transformowanie znaczeń, do których odsyłają i które są wytwarzane w czaso-przestrzeni intersubiektywności za pomocą pracy głosu jako

\footnotetext{
${ }^{27}$ Nie podejmuję w tym miejscu wątku, jak w późnej filozofii Wittgensteina jest ujmowany sposób życia, ponieważ wykraczałoby to poza ramy merytoryczne niniejszego artykułu, choć niewątpliwie wiele poruszanych w nim kwestii by rozjaśnił. Osoby zainteresowane odsyłam do lektury książki P. Dehnela (2016), do stron 295-328.

28 Dehnel, analizując antropologiczną perspektywę Wittgensteina, podaje przykład użycia słowa „ból”, którego znaczenia nie da się sprowadzić do subiektywnych doznań. Znaczenia słowa „ból” „uczą nas rodzice, kiedy proszą: «Pokaż rączką, gdzie cię boli?», «Tu cię boli?», «Bardzo boli?», «Zaraz przestanie». A kiedy już umiemy trochę mówić pytają: «Powiedz co cię boli?» «Brzuszek cię boli?». «To jest brzuszek, on cię boli?», «Tak cię tam kłuje?». Dziecko uczy się przez to nie tylko znaczenia znaczenia słowa ból, ale tego, czym jest ból. Uczy się tego również przez obserwację Drugich: widzi na przykład tatę, którego boli głowa i który nie chce się bawić, jest markotny, trzyma się za czoło albo idzie się położyć, a mama prosi: «nie hałasuj, proszę, tatę boli głowa», «weźmie tabletkę i zaraz do ciebie przyjdzie». Z tych nieskończenie wielu reakcji i obserwacji dowiadujemy się, co znaczy boleć i jak się zachowujemy, kiedy coś nas boli" (Dehnel 2016: 285-286).

${ }^{29}$ Shaun Gallagher i Dan Zahavi w książce pt. Fenomenologiczny umysł przywołują badania W. Fifera i Ch. Moon oraz A. DeCaspera i M.J. Spence i proponują, aby zdolność mówienia małych dzieci do 2 roku życia (a przede wszystkim noworodków) nie określać jako przedjęzykową czy wstępną, ale właśnie jako protojęzykową (Gallagher, Zahavi 2015: 148). Analogicznie można odnieść się do pojęcia „pierwszego" człowieka, które ewoluowało od ujęcia go jako człowieka dzikiego czy prymitywnego do ujęcia go jako człowieka pierwotnego.
} 
nie tylko nośnika tych znaczeń, ale jako drogi docierania do Drugiego - do tego oto małego dziecka. Jak żywe słowo, czyli słowo działające, kształtować i praktykować w relacji dorosły - małe dziecko? To pytanie, na które warto poszukać odpowiedzi, mając zarazem na uwadze, że dorosły mówi i myśli przede wszystkim w języku werbalno-pojęciowym, małe dziecko, zanim wytworzy język obrazowy, smakuje wydawane przez siebie dźwięki pierwszych głosek, sylab i słów, jakże jeszcze śmiesznie brzmiących dla dorosłego. Formowanie słów przez dorosłego i tego, co niewypowiedziane - umiejętność bycia w milczeniu z małym dzieckiem, staje się arcyważne. Słowa - wstępując do świata małego dziecka - w tym świecie się zadamawiają, czyniąc go nie tylko zrozumiałym dla niego, ale i ważnym. Jakie słowa będą ważne w świecie małego dziecka, a później dorosłego zależy od tego, jakie rodzaje słów - wypowiadane i nie-wypowiadane przez dorosłego - fundują jego świat. W przestrzeni jakich słów przebywa dziecko? Do czego słowa dorosłego służą? Co wypowiadają? Jakich słów w tej przestrzeni nie ma? Czy w przestrzeni słów jest miejsce na ciszę i milczenie? 0 tyle i tak małe dziecko odbiera znaczenia słów i milczenie jako dzieło mówienia dorosłego, o ile mają one jemu coś do powiedzenia $^{30}$. Merleau-Ponty pisał: „(...) wszystko, co może mieć kiedykolwiek wartość w moich oczach, osiąga ją jedynie wówczas, gdy, bezpośrednio lub nie wprost, wkracza do mojego pola, ukazuje się w bilansie mojego doświadczenia, wstępuje do mojego świata (...)" (Merleau-Ponty 1999: 67).

\section{Zamiast zakończenia}

Inspirując się słowami Merleau-Ponty, jeśli chcemy przybliżyć sobie sens „pracy mowy" w relacji dorosły - małe dziecko, trzeba zamienić strony relacji i spojrzeć z perspektywy małego dziecka, które znajduje się w gąszczu mowy dorosłego. Jeśli chcemy mu pomóc w poruszaniu się w tym gąszczu, trzeba nam uchwycić „pierwotną operację znaczeniową mowy” - „(...) musimy udawać, że nigdy dotąd nie mówiliśmy, (...) musimy spojrzeć na nią, jak głuchy na mówiącego, porównać sztukę mowy z innymi sztukami ekspresji, które się do niej nie odwołują, spróbować dojrzeć w niej jedną ze sztuk niemych" (tamże: 156). Trzeba niezwykłego taktu i umiejętności, aby mówić do małego dziecka w języku, który jest dla niego językiem obcym.

\footnotetext{
${ }^{30}$ Dziecko nie obcuje z czyimiś słowami i wyrażonymi w nich myślami, lecz z mówiącym człowiekiem, którego mówienie jest przejawem pewnej „modulacji istnienia”, człowiekiem i jego stylem bycia „Z pewnym stylem bycia oraz ze światem, który wyznacza” (Merleau-Ponty 1999: 104).
} 


\section{Bibliografia}

Andrzejewski B. (2016) Filozofia słowa. Zarys dziejów, Poznań, Wydawnictwo Naukowe UAM.

Dehnel P. (2016) Myśli a sposoby życia. Eseje o filozofii współczesnej, Warszawa, Universitas.

Derrida J. (1997) Głos i fenomen. Wprowadzenie do problematyki znaku w fenomenologii Husserla, tłum. B. Baran, Warszawa, Fundacja Aletheia.

Dudek Z. W. (2005) Psychologiczny język kultury w: W. Z. Dudek, A. Pankalla, Psychologia kultury. Doświadczenia graniczne i transkulturowe, Warszawa, Wydawnictwo Psychologii i Kultury ENETEIA.

Filek J. (2014) Filozofa wstęp do ciszy, Wydawnictwo Znak, nr 707.

Gadamer H.-G. (1993) Prawda i metoda. Zarys hermeneutyki filozoficznej, tłum. i wstęp B. Baran, Kraków, inter esse.

Gadamer H.-G. (2008) Teoria, etyka, edukacja. Eseje wybrane, wstęp i redakcja naukowa P. Dybel, Warszawa, Wydawnictwo Uniwersytetu Warszawskiego.

Gallagher S., Zahavi D. (2015) Fenomenologiczny umyst, tłum. i przedmowa M. Pokropski, Warszawa, Wydawnictwo Naukowe PWN.

Heidegger M. (1999) Ku rzeczy myślenia, tłum. K. Michalski, J. Mizera, C. Wodziński, Fundacja Aletheia.

Heidegger M. (2000), W drodze do języka, tłum. J. Mizera, Kraków, Baran i Suszczyński.

Heidegger M. (2009) Podstawowe problemy fenomenologii, tłum. B. Baran, Warszawa, Fundacja Aletheia.

Jaspers K. (1990) Język w: Filozofia egzystencji. Wybór pism, tłum. D. Lachowska, A. Wołkowicz, Warszawa, Państwowy Instytut Wydawniczy.

Jaspers K. (1999) Wiara filozoficzna wobec objawienia, tłum. G. Sowiński, Kraków, Wydawnictwo Znak.

Lévinas E. (1998) Całość i nieskończoność, tłum. M. Kowalska, Wstęp B. Skarga, Warszawa, Wydawnictwo Naukowe PWN.

Lévinas E. (2000) Inaczej niż być lub ponad istotą, tłum. P. Mrówczyński, Warszawa, Fundacja Aletheia. 
Lévinas E. (2008) Bóg, śmierć i czas, tłum. J. Margański, Kraków, Wydawnictwo Znak. Mech K. (2014) O możliwości poznania Drugiego, „Filozofia religii”, nr 1, s. 1-53.

Merleau-Ponty (1996) Oko i umysł. Szkice o malarstwie, tłum. E. Bieńkowska, S. Cichowicz, Gdańsk, słowo/obraz terytoria.

Merleau-Ponty M. (1999) Proza świata. Eseje o mowie, tłum. E. Bieńkowska, S. Cichowicz, Joanna Skoczylas, Warszawa, Czytelnik.

Merleau-Ponty M. (2001) Fenomenologia percepcji, tłum. M. Kowalska, J. Migasiński, Warszawa, Fundacja Aletheia.

Michalik J. (2010) Filozofia głosu, Kraków, NOMOS.

Michalik J. (2011) Głos - transcendencja w języku: o fenomenologii mowy Maurice'a Merleau-Ponty'ego, „Sztuka i Filozofia”, nr 33.

Opoczyńska M. (2016) Genealogie psychoterapii. Fragmenty dyskursu egzystencjalnego, Kraków, Wydawnictwo Uniwersytetu Jagiellońskiego.

Ricoeur P. (1991) Podług nadziei. Odczyty, szkice, studia, tłum. S. Cichowicz, Warszawa, Instytut Wydawniczy PAX.

Ricoeur P. (2005) O sobie samym jako innym, tłum. B. Chełstowski, Wstęp M. Kowalska, Warszawa, Wydawnictwo Naukowe PWN.

Saint-Exupéry de A. (2000) Mały Ksiq̨żę, tłum. E. Łozińska-Małkiewicz, Toruń, Algo.

Skarga B. (2004) Co zwie się myśleniem w: taż, Ślad i obecność, Warszawa, Wydawnictwo Naukowe PWN.

Walczak A. (2011) Symbolika Innego jako Drugiego w: taż, Spotkanie z wychowankiem. Ku tożsamości ipse pedagoga, Łódź, Wydawnictwo Uniwersytetu Łódzkiego.

Walczak A. (2016) Etyka (w) codzienności wychowania - od nieuchronności do możliwości, „Nauki o Wychowaniu. Studia Interdyscyplinarne”, nr 2.

Wittgenstein L. (2000) Dociekania filozoficzne, tłum. B. Wolniewicz, Warszawa, Wydawnictwo Naukowe PWN.

Zając-Jamróz J. (2012) W stronę antropologii słowa. Mieczysław Kotlarczyk, Kristin Linklater, Zygmunt Molik, Zeszyty Naukowe Państwowej Wyższej Szkoły Teatralnej w Krakowie, nr 4. 